\title{
Challenges met by Healthcare Professionals (Nurses) at the time of Covid-19 Pandemic
}

\section{Introduction:}

The fast-growing Covid-19 pandemic has a great health problem to people in worldwide and has a major challenge for nurses and other health care professionals as well as nursing students. Here, few major challenges are listed that the health care workers (HCW) especially Nurses are faced and facing many problems in their dayto-day life.

\section{Major Challenges are facing by the nurses:}

Increased risk of infection among nurses: The reports from across the world shows that the healthcare workers were affected by Covid-19 outbreak in the early period. [1] It was particularly nurses who took care of Covid-19 unit are getting infected or dying due to Covid-19 most of the hospitals and isolation centres were overloaded by Covid cases which leads to nurses are susceptible to infection. But now this situation is changed in few hospitals because of awareness of Covid outbreaks.

\section{Lack of awareness of Covid-19 among Healthcare}

Workers: As this disease has spread suddenly the nurses were not aware about this type of disease will go worst. But now nurses are prepared in somewhat extent for future Covid out breaks. Now, a day's most of the hospitals also prepared with adequate ICU and emergency rooms. Few countries like Hong Kong, Taiwan, Singapore are already learned the lessons well from SARS and H1N1 out breaks. The health care workers in those countries already aware about these pandemic outbreaks. [2]

\section{Shortage of experienced nurses in Covid-19 unites:}

In most of the hospitals the nurse's patient ratio need to be well maintained as it highly affects the healthcare delivery system. Professional training includes the hazards of disease, and its routes, routes of transmission, personal protection, prevention and control measures will extend the knowledge and skill of nurses and nursing students, who might be brought to the pandemic to support their colleagues when there are sufficient trained nurses can have more advocate with patient and their relatives about patient care. [3]

\section{Shortage of personal protection equipment:}

There is a shortage of PPE in most hospitals and health centers in India including face mask, gowns and respirators. Local product of face mask and other kits are reported to be of low quality which is not protective against infection. [3]

\section{Long working hours:}

Shortage of staff pattern results in long working hours and sometimes double shift also some nurses care needs to do. [3]

\section{Inadequate quarantine facilities:}

In earlier period of this outbreaks the nurses are quarantined between $14-15$ days after they completed one rotation of duty. But, later as the cases increases the rules of quarantine period was reduced to 2 to 3 days which is happened particularly the Urban Centre of Delhi and Mumbai. The rules of testing the health workers also changed which leads to increased incidence of infection among nurses. [4]

\section{Mental Violence:}

It will lead to inefficient care nurses facing mental violence can be in the form of threats, verbal abuse, hostility and possible source of violence includes patient, visitors and co-workers. [3, 5]

Article Summary: Submitted:26-October-2021 Revised:10-November-2021 Accepted:02-December-2021 Published:31-December-2021

\begin{tabular}{|c|c|c|}
\hline \multirow[t]{3}{*}{ Quick Response Code: } & \multirow{3}{*}{$\begin{array}{c}\text { Web Site } \\
\text { http://ijmsnr.com/ }\end{array}$} & \multirow[b]{2}{*}{$\begin{array}{l}\text { This is an open access journal, and articles are distributed under the terms of the } \\
\text { Creative Commons Attribution-Non-Commercial-ShareAlike } 4.0 \text { International } \\
\text { License, which allows others to remix, tweak, and build upon the work } \\
\text { non-commercially, as long as appropriate credit is given and the new creations are } \\
\text { licensed under the identical terms. }\end{array}$} \\
\hline & & \\
\hline & & $\begin{array}{l}\text { How to cite this article: Senthilvel S. Challenges met by healthcare } \\
\text { professionals (Nurses) at the time of Covid-19 Pandemic. Int J Med Sci } \\
\text { and Nurs Res } 2021 ; 1(2): 3-4 \text {. }\end{array}$ \\
\hline
\end{tabular}




\section{Lack of teamwork:}

One of the highly sought-after tools in the field of human resource management in team work. Since there is lack of team work in Covid-19 management working as a team will get and share innovative ideas to tackle this Covid-19 pandemic.

\section{Importance of nursing administration:}

The nursing service and administration is very important and essential in the COVID-19 care unit. In Saudi Arabia, the MOH has collaborated with the private sector and planned to sector wise and nursing administration to strengthen in all the levels. [6]

\section{Conclusion:}

Nurses are playing important role in the battle against COVID unit. Nurses are facing challenges while working in COVID care unites as mentioned like risk of infection, more working hours, lack of awareness and etc. These challenges immediately need to meet which will be improving efficient nursing care in COVID-19 pandemic. More training programs and researchers are needed to the healthcare workers (Staff Nurses) to prepare them for future pandemics.

\section{References:}

1. Lai X, Wang M, Qin D, Tan L, Ran L, Chen D, et. al. Coronavirus Disease 2019 (Covid-2019) Infection Among Health Care Workers and Implications for Prevention Measures in a Tertiary Hospital in Wuhan, China. JAMA Netw Open 2020;3(5):e209666. DOI: 10.1001/jamanetworkopen.2020.9666.

2. Tripathi R, Alqahtani SS, Albarraq AA, Meraya AM, Tripathi P, Banji D, et al. Awareness and preparedness of COVID-19 Outbreak Among Healthcare Workers and Other Residents of South-West Saudi Arabia: A Cross-Sectional Survey. Front Public Helath 2020;8:482. DOI: 10.3389/fpubh.2020.00482.

3. Challenges in Nursing: What Do Nursing Face on a Daily Basis Available on: https://online.arbor.edu/news/challenges-in-nursing [Last Accessed on 18 July 2021]

4. Nurses concerned of COVID-19 exposure, lack of quarantine quarters. Available on: https://www.breakingbelizenews.com/2020/08/08/nursesconcerned-of-covid-19-exposure-lack-of-quarantine-quarters/ Last Accessed on 19 July 2021]

5. Chhugani M, James MM. Challenges faced by nurses in India-the major workforce of the healthcare system. Nursing \& Care Open Access Journal 2017;2(4):112-114. DOI: 10.15406/ncoaj.2017.02.00045.

Publish your research articles with International Journal of Medical Sciences and Medical Research Website: http://ijmsnr.com/
6. Alluhidan M, Tashkandi N, Alblowi F, Omer T, Alghaith T, Alghodaier $\mathrm{H}$, et al. Challenges and policy opportunities in nursing in Saudi Arabia. Human Resources for Health 2020;18:98. DOI: 10.1186/s12960-020-00535-2.

\section{Mrs. Sumathi Senthilvel,}

\author{
M.Sc., (Nursing), RN., RM., \\ Associate Editor, IJMSNR, \\ Formerly Assistant Professor in Nursing, \\ Department of Fundamental Nursing, \\ Amrita College of Nursing. Ponekkara, Kochi, Kerala. \\ Email ID: AssociateEditor@ijmsnr.com
}

